\title{
Physicochemistry, microbiology, fatty acids composition and volatile profile of traditional Söğle tulum (goat's skin bag) cheese
}

\author{
OGUZ GURSOY ${ }^{1}$, AHMET KÜÇÜKÇETİN ${ }^{2}$, ÖZGE GÖKÇE ${ }^{3}$, FİRUZE ERGİN ${ }^{2}$ and KÜBRA KOCATÜRK ${ }^{4}$ \\ ${ }^{1}$ Department of Food Engineering, Faculty of Engineering and Architecture, Burdur \\ Mehmet Akif Ersoy University, Istiklal Campus, 15030 Burdur, Turkey \\ ${ }^{2}$ Department of Food Engineering, Faculty of Engineering, Akdeniz University, Dumlupinar Bulvari, 07058 Antalya, Turkey \\ ${ }^{3}$ Scientific and Technological Research and Application Center, Burdur Mehmet \\ Akif Ersoy University, Istiklal Campus, 15030 Burdur, Turkey \\ ${ }^{4}$ Department of Food Engineering, Institute of Natural and Applied Sciences, Burdur \\ Mehmet Akif Ersoy University, Istiklal Campus, 15030 Burdur, Turkey
}

Manuscript received on March 26, 2018; accepted for publication on May 21, 2018

\begin{abstract}
Söğle cheese is a type of traditional tulum (goat's skin bag) cheese produced from goat's milk or a mixture of goat's and sheep's milk in Küçük Söğle and Büyük Söğle villages, Antalya, Turkey. This is the first study that aimed to investigate the physicochemistry, microbiology, fatty acids composition and volatile profile of traditional Söğle cheeses ripened in goat's skins for three months in wells. The $\mathrm{pH}$ and titratable acidity values, total solids, fat, protein and salt contents of the Söğle cheese samples ranged from 4.9 to 5.5, from 1.4 to $2.6 \%$, from 46.5 to $55.0 \%$, from 2.0 to $4.5 \%$, from 34.9 and $42.2 \%$ and from 4.1 to $8.2 \%$, respectively. The highest proportion of fatty acids in all cheese samples was palmitic acid (C16:0). The lactobacillus, lactococcus, total aerobic mesophilic bacteria and yeast and mold counts in the cheese samples were found to be between 7.1 and $8.5 \log \mathrm{cfu} / \mathrm{g}, 7.8$ and $8.7 \log \mathrm{cfu} / \mathrm{g}, 7.6$ and $8.5 \log \mathrm{cfu} / \mathrm{g}$ and 1.0 and $4.8 \log \mathrm{cfu} / \mathrm{g}$, respectively. Fifty-three volatile components were identified in the cheese samples including 13 esters, 7 ketones, 5 acids, 2 aldehydes, 5 alcohols, 12 terpenes, and 9 miscellaneous compounds. Ketones and terpenes were the predominant volatile compounds.
\end{abstract}

Key words: traditional cheese, goat's skin bag, Tulum, volatile composition.

\section{INTRODUCTION}

Traditional products have specific characteristics that differentiate them from other similar products in the same category by use of traditional ingredients, traditional composition or traditional type of production and/or processing method. In recent years, there has been a growing interest in

Correspondence to: Oguz Gursoy

E-mail: ogursoy@yahoo.com / ogursoy@mehmetakif.edu.tr consuming traditional cheeses in many countries, including Turkey, mainly because of non-use of any additives in their production process and their beneficial effects on human health (Hayaloglu et al. 2007, Shahbazi et al. 2017). As one of the most popular cheese types, tulum cheese made either from sheep's milk, goat's milk, a combination of sheep's and goat's milk, or cow's milk is traditionally produced in many regions of Turkey (Sert and Akin 2008). Tulum cheese types are 
named according to the regions where they are produced, such as Erzincan (Savak), Divle, Cimi and Izmir (Bayar and Ozrenk 2011, Adanacioglu and Albayram 2012).

Söğle cheese is a type of tulum cheese produced from May to September when milk is abundant in Küçük Söğle and Büyük Söğle villages, located in the town of Elmalı in the province of Antalya, in Turkey (Figure 1). Söğle cheese is made from goat's milk or a mixture of goat's and sheep's milk without using any starter culture. Cheese milk prepared from goat's milk or a mixture of sheep's and goat's milk is heated to $40^{\circ} \mathrm{C}$ in wood fire and skimmed by commercial small fat separators according to the producers' needs. Then, commercial rennet (1/20000: Mayasan Food Industries AS, Istanbul, Turkey) is added to the skimmed milk. After coagulation of the skimmed milk in about $35 \mathrm{~min}$, the curd is heated to $50^{\circ} \mathrm{C}$. The heated curd is poured into plastic bags, and then kept at ambient temperature (about 15$20^{\circ} \mathrm{C}$ ) for five days for whey draining. After whey draining, the curd is crumbled by hand and drysalted. The crumbled and salted curd is transferred into the new plastic bags and kept under pressure by placing stones on these plastic bags at ambient temperature for two days. At the end of the second day, the curd is crumbled by hand and dry-salted for a second time. Then, the curd is filled into the tulum (goat-skin bag), excessive air in the tulum is removed by placing stones on the tulum. Söğle cheese in the tulum is ripened in wells with a depth of about 10 meters and at a temperature of about $10^{\circ} \mathrm{C}$ for 3 months. Söğle cheese has high dry matter and protein contents with a crumbly texture and a piquant flavor. Physicochemical and microbiological properties of tulum cheeses include Söğle cheese vary depending on type and microbial diversity of raw milk, production method, and ripening conditions such as temperature, time and cheese packaging material (Sert et al. 2014). Moreover, physicochemical and microbiological properties of some of tulum cheese types such as Erzincan, Cimi,
Divle and Karg1 have been introduced in previous studies. Cheese properties vary according to geographical features of the region in which the milk animals are fed, such as geology, climate, pedology and topography, natural microbial and botanical flora, and production methods (Karoui et al. 2005). Söğle cheese is a type of tulum cheese, however the milk used in the production of Söğle cheese is not used in the production of any other tulum cheese types. Therefore, because of the composition of milk used in production of Söğle cheese and some differences in its production method (e.g. ripening in wells located in Söğle plateau for three months and heat treatment by using wood fire), Söğle cheese has its own characteristics which make it different from other tulum cheese types. To the best of our knowledge, there is no study in the scientific literature that has focused on Söğle cheese. The aim of this study was to investigate the physicochemical and microbiological properties, fatty acid composition and volatile profile of Söğle cheese.

\section{MATERIALS AND METHODS}

\section{MATERIALS}

Five different Söğle cheeses $(\mathrm{C} 1, \mathrm{C} 2, \mathrm{C} 3, \mathrm{C} 4$, and $\mathrm{C} 5)$ ripened for three months in wells located in Söğle plateau (altitude of 1400 m, Elmalı, Antalya) were collected from different local producers in Büyük Söğle and Küçük Söğle villages in October 2017. Sample photographs of collected cheeses C1 and C4 produced in Büyük Söğle and Küçük Söğle villages are given in Figure 2. The cheeses $\mathrm{C} 1, \mathrm{C} 2$ and $\mathrm{C} 3$ were produced with a mixture of goat's (80\%) and sheep's milk (20\%) while the cheeses $\mathrm{C} 4$ and $\mathrm{C} 5$ were produced with goat milk (100\%). All milks used in Söğle cheese production were skimmed by centrifugation. The cheeses were individually vacuum packed after purchase and stored at $4{ }^{\circ} \mathrm{C}$ until analysis carried out. 

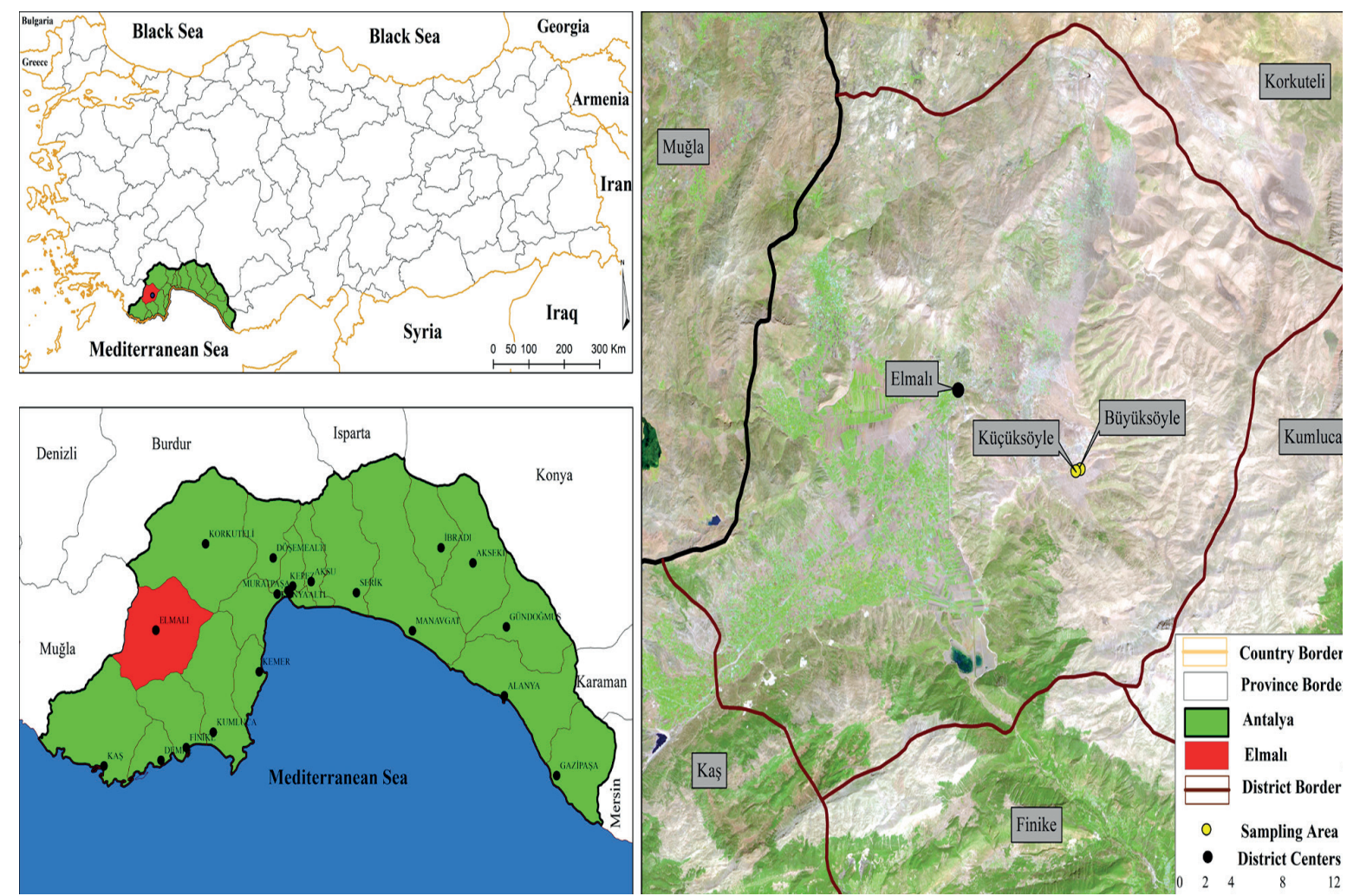

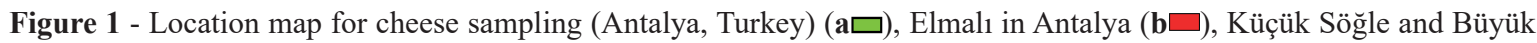
Söğle villages in Elmalı (c $\bigcirc)$.

\section{PHYSICOCHEMICAL ANALYSES}

The cheese samples were analyzed for total solids by the gravimetric method, and for fat by the Gerber method (Turkish Standards Institute 1995). The $\mathrm{pH}$ values of the cheeses were measured using a $\mathrm{pH}$-meter (6173 $\mathrm{pH}$, Jenco, USA) and the titratable acidity was determined as \% lactic acid according to Turkish Standards (Turkish Standards Institute 1995). The measurement of salt contents in the cheese samples was carried out by the Mohr titration method (Turkish Standards Institute 1995), and total nitrogen contents of the cheeses were determined by the Dumas method by the Dumatherm analyzer (Gerhardt GmbH \& Co. KG, Königswinter, Germany). Protein content was calculated by using the factor 6.38 .

\section{FATTY ACID ANALYSIS}

Fat from the cheese samples was extracted according to the method of Renner (1993).
Cheese samples (about $20 \mathrm{~g}$ ) were ground with 6-8 g of kieselguhr (Fluka Chemie GmbH, Buchs, Switzerland) and mixed with $200 \mathrm{~mL}$ diethyl ether (Fluka Chemie GmbH, Buchs, Switzerland). The mixture was blended for $1 \mathrm{~min}$ and was filtered using rough filter paper $(0.18 \mathrm{~mm}$ in thickness, $82 \mathrm{~g} / \mathrm{m}^{2}$ in weight). The filtered solution (diethyl ether-lipid extracts) was concentrated using a rotary evaporator (Scilogex, USA) at $40^{\circ} \mathrm{C}$ under vacuum to a final volume of approximately $1-3 \mathrm{~mL}$ for analysis. The lipid extracts were flushed with nitrogen until dry, and stored at $-20^{\circ} \mathrm{C}$ for further analysis in glass vials. Fatty acid methyl esters (FAMEs) were prepared according to Yilmazer and Secilmis (2006). One mL of 1.5 M methanolic $\mathrm{HCl}$ was added to extracted fat sample $(200 \mu \mathrm{L})$ and kept at $80^{\circ} \mathrm{C}$ for two hours. Then, it was cooled to room temperature and $0.5 \mathrm{~mL}$ water was added, and the FAMEs were extracted using $1 \mathrm{~mL}$ hexane. 

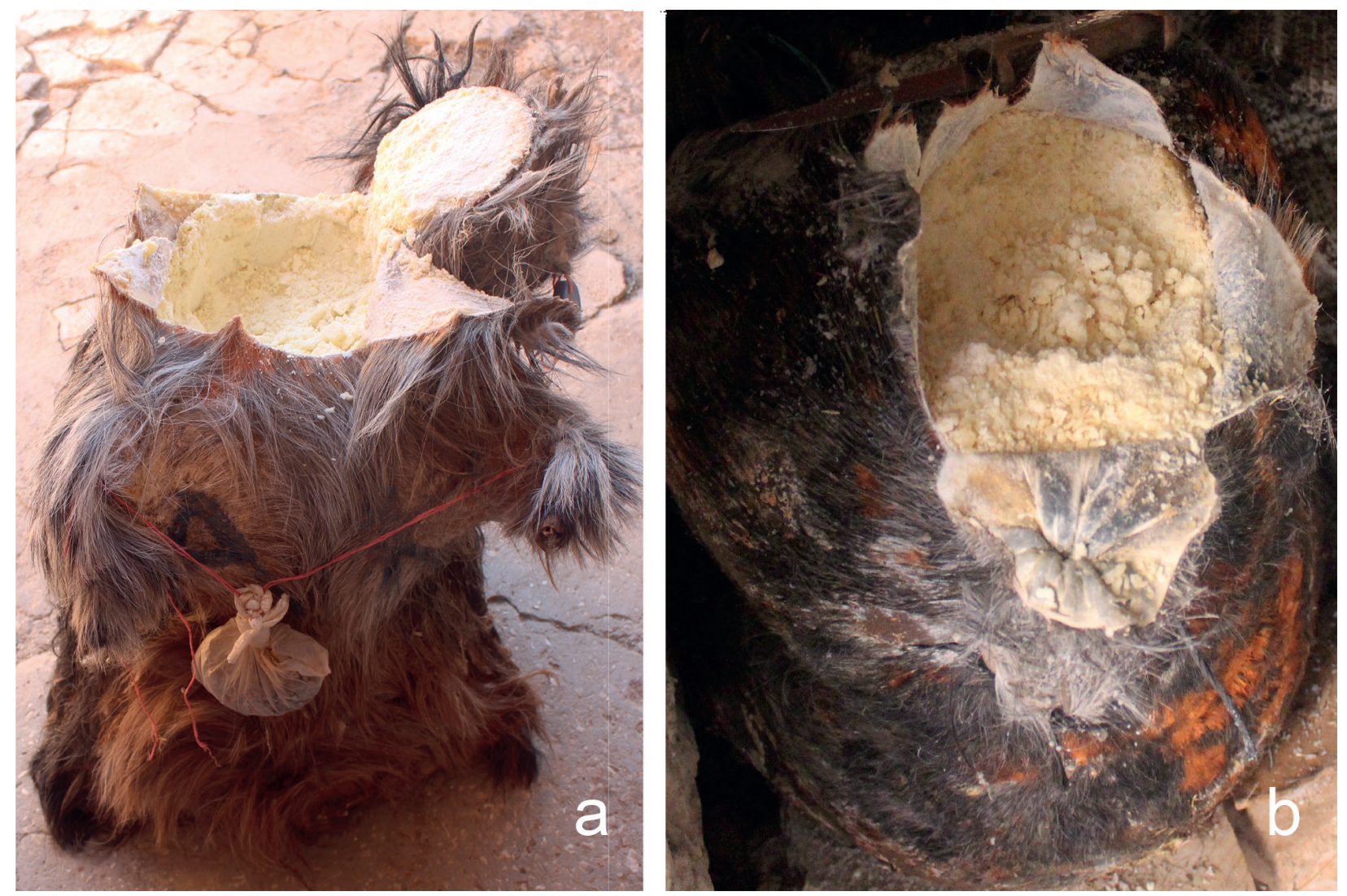

Figure 2 - Photographs of collected Söğle tulum cheeses C1 (a) and C4 (b) produced in Büyük Söğle and Küçük Söğle villages, Elmalı, Antalya, Turkey.

Fatty acids analysis was carried out using an Agilent 78890A (Agilent Technologies, Wilmington, DE, USA) gas chromatograph equipped with a Agilent 5975 C (Agilent Technologies, Wilmington, DE, USA) quadrapole mass spectrometer detector (MS) operated in the electron impact ionization mode at $70 \mathrm{eV}$. Fragment ions were analyzed over 30$500 \mathrm{~m} / \mathrm{z}$ mass range in scan mode. Analysis was performed with a CP-SIL 88 fused silica capillary column for FAME (100 m x $0.25 \mathrm{~mm}$ i.d., 0.2 $\mu \mathrm{m}$ film thickness; Chrompack, Midelburg, The Netherlands). The injection volume was $1 \mu \mathrm{L}$. Injector and detector temperatures were $240^{\circ} \mathrm{C}$. Helium was used as the carrier gas and the flow rate was $1 \mathrm{~mL} / \mathrm{min}$. Temperature of column oven was programmed to $60^{\circ} \mathrm{C}$ for $4 \mathrm{~min}$, from 60 to $175^{\circ} \mathrm{C}$ at $13^{\circ} \mathrm{C} / \mathrm{min}$ for $27 \mathrm{~min}$, from 175 to $215^{\circ} \mathrm{C}$ at $4^{\circ} \mathrm{C} /$ $\min$ for $5 \mathrm{~min}, 215$ to $240^{\circ} \mathrm{C}$ at $4^{\circ} \mathrm{C} / \mathrm{min}$ for $15 \mathrm{~min}$.
The split ratio was set to 1:20. Data handling was performed using MSDCHEM software. Standard mix of FAMEs (Supelco® 37 Component FAME Mix, Cat. No. 47885 U) was obtained from SigmaAldrich (Interlab A.S., Istanbul, Turkey).

\section{VOLATILE COMPOUND ANALYSIS}

Grated cheese sample ( $3 \mathrm{~g})$ was placed in $15 \mathrm{~mL}$ glass vial with PTFE/silicone septa (Supelco, 27159) and the vial was kept in a water bath at $45^{\circ} \mathrm{C}$ for $15 \mathrm{~min}$. The volatile compounds of the sample were adsorbed from headspace of vial by Carboxen ${ }^{\circledR} /$ Polydimethylsiloxane (CAR/PDMS) $75 \mu \mathrm{m}$ fibre with a manual holder (Supelco, Cat No.: 57318, Bellefonte, Pennsylvania, USA) at $45^{\circ} \mathrm{C}$ for $30 \mathrm{~min}$. The fibre was properly conditioned before the initial use in GC injector according to the instructions provided by the manufacturer. 
After sampling the SPME, fibre was immediately thermally desorbed into the GC injection port. A desorption time of $5 \mathrm{~min}$ at $250^{\circ} \mathrm{C}$ was adopted. The volatiles were analyzed by a Shimadzu GCMS-QP2010 SE (Shimadzu Co., Kyoto, Japan) gas chromatography-mass spectrometry (GC-MS) equipped with low-polarity Rxi-5Sil MS fusedsilica column $(30 \mathrm{~m} \times 0.25 \mathrm{~mm}$ internal diameter (id) $\times 0.25 \mu \mathrm{m}$ film thickness (df), Cat No.: 13623; Restek Corp., Bellefonte, PA, USA). Injector and detector temperatures were $250^{\circ} \mathrm{C}$. Helium was used as the carrier gas and the flow rate was 1.61 $\mathrm{mL} / \mathrm{min}$. The injection was performed in split mode with a split ratio of 10:1. Temperature of column oven was set to increasing from $40^{\circ} \mathrm{C}(2$ min holding time) to $250^{\circ} \mathrm{C}$ at the rate of $4^{\circ} \mathrm{C} / \mathrm{min}$ (5 min holding time at $250^{\circ} \mathrm{C}$ ). MS detector was operated in the electron impact ionization mode at $70 \mathrm{eV}$. The mass spectra of the individual volatile compounds were compared to those provided by the National Institute of Standards and Technology (NIST) library, Wiley, Tutor, Flavor and Fragrance Natural and Synthetic Compounds (FFNSC).

\section{MICROBIOLOGICAL ANALYSES}

Ten gram of cheese samples were diluted with $90 \mathrm{~mL}$ sterile Ringer solution (1/4 strength) in a polyethylene bag and homogenized using a Stomacher (Seward 80 Biomaster, Seward Limited, West Sussex, United Kingdom). Serial dilutions were made and appropriate dilutions were plated onto the selective media. The number of total aerobic mesophilic bacteria in the cheese samples was determined on Plate Count Agar (PCA) incubated aerobically at $30^{\circ} \mathrm{C}$ for $48 \mathrm{~h}$. The counts of lactobacilli and lactococci in the samples were measured with MRS (de Man, Rogosa and Sharpe) Agar at $35^{\circ} \mathrm{C}$ for $72 \mathrm{~h}$ and with M17 Agar at $37^{\circ} \mathrm{C}$ for $48 \mathrm{~h}$, respectively. Yeasts and molds were enumerated using Potato Dextrose Agar (PDA) incubated aerobically at $24^{\circ} \mathrm{C}$ for five days (Karagozlu et al. 2009).

\section{RESULTS AND DISCUSSION}

The $\mathrm{pH}$ and titratable acidity values and the total solids (TS), fat, fat in TS, protein, protein in TS, salt and salt in TS contents of the Söğle cheeses are given in Table I. The $\mathrm{pH}$ and titratable acidity values of the Söğle cheese samples ranged from 4.9 to 5.5 and from 1.4 to $2.6 \%$, respectively. The results of the $\mathrm{pH}$ measurements in the samples are in agreement with other researches, while the titratable acidity values in 3 of 5 samples were higher than the values reported in other studies (Tarakci and Durmus 2016, Sert et al. 2014). Lactic acid bacteria, which are naturally present in raw milk, can produce high concentration of lactic acid from lactose that results in an increase in the acidity of cheese (Gurses and Erdogan 2006). Dinkci et al. (2007) presented that levels of citric acid, acetic acid, propionic acid and formic acid were unexpectedly high in Karg1 tulum cheese due to the heterofermentative metabolism of nonstarter microbiota that can produce some organic acids from lactose and lactic acid. In our study, TS contents of the Söğle cheese samples varied from 46.5 to $55.0 \%$, as shown in Table I. Hayaloglu et al. (2007) have reported that the average TS contents of tulum cheeses ripened in plastic or goat's skin bags for 90 days were between 51.0 and $61.4 \%$. The TS contents of tulum cheeses should be higher than $55 \%$ according to the regulation for tulum cheese prescribed by Turkish Food Codex (Ministry of Agriculture and Forestry 2015). The TS contents in 4 out of 5 Söğle cheese samples were lower than the limit set by the Turkish Food Codex. The mean fat and fat in TS contents of Söğle cheese samples varied from 2.0 to $4.5 \%$ and from 3.6 to $9.3 \%$, respectively. The fat in TS contents determined in Söğle cheese samples were lower than those reported by some authors, including Hayaloglu et al. (2007), Dinkci et al. (2012) and Sengul et al. (2014). Söğle cheese can be considered as a variety of fat-free cheese, because cheese with 
TABLE I

Physicochemical characteristics of Söğle cheese samples ripened for three months $(n=2)$ *.

\begin{tabular}{cccccc}
\hline \multirow{2}{*}{ Analysis } & \multicolumn{5}{c}{ Cheese Samples } \\
\cline { 2 - 6 } & $\mathbf{C 1}$ & $\mathbf{C 2}$ & $\mathbf{C 3}$ & $\mathbf{C 4}$ & $\mathbf{C 5}$ \\
\hline $\mathrm{pH}$ & $5.0 \pm 0.0$ & $5.3 \pm 0.0$ & $4.9 \pm 0.0$ & $5.5 \pm 0.0$ & $5.1 \pm 0.0$ \\
Titratable acidity (\%) & $2.6 \pm 0.0$ & $1.6 \pm 0.0$ & $2.4 \pm 0.0$ & $1.4 \pm 0.0$ & $2.0 \pm 0.0$ \\
Total solids (TS) (\%) & $48.3 \pm 0.2$ & $48.0 \pm 0.0$ & $54.4 \pm 0.0$ & $55.0 \pm 0.1$ & $46.5 \pm 0.2$ \\
Fat (\%) & $4.5 \pm 0.0$ & $2.0 \pm 0.0$ & $4.0 \pm 0.0$ & $2.0 \pm 0.0$ & $2.5 \pm 0.0$ \\
Fat in TS (\%) & $9.3 \pm 0.0$ & $4.2 \pm 0.1$ & $7.4 \pm 0.0$ & $3.6 \pm 0.0$ & $5.4 \pm 0.0$ \\
Protein (\%) & $37.3 \pm 0.1$ & $36.9 \pm 0.6$ & $39.3 \pm 0.2$ & $42.0 \pm 0.5$ & $34.9 \pm 0.9$ \\
Salt (\%) & $4.1 \pm 0.0$ & $6.2 \pm 0.2$ & $8.2 \pm 0.1$ & $5.8 \pm 0.0$ & $5.2 \pm 0.1$ \\
Salt in TS (\%) & $8.6 \pm 0.1$ & $12.8 \pm 0.3$ & $15.0 \pm 0.1$ & $10.6 \pm 0.0$ & $11.2 \pm 0.1$ \\
\hline
\end{tabular}

*The presented values are the means \pm standard deviation $(n=2)$.

fat in TS less than $10 \%$ is classified as fat-free cheese, according to the regulation of Turkish Food Codex for tulum cheese (Ministry of Agriculture and Forestry 2015). Thus, the low TS contents in Söğle cheese samples were associated with the low fat contents in them. The protein contents in Söğle cheese samples ranged from 34.9 to $42.2 \%$. Protein contents of the Söğle cheese samples were found to be higher than those reported in previous studies (Bayar and Özrenk 2011, Sengul et al. 2014, Tarakci and Durmus 2016, Celik and Tarakci 2017).

Salt contents affect microbial and enzymatic activities in cheese by controlling water activity, and change the biochemical, textural and sensory properties of cheese during ripening (Guinee 2004). Salt and salt in TS of Söğle cheese samples ranged from 4.1 to $8.2 \%$ and from 8.6 to $15.0 \%$, respectively. According to the Turkish Food Codex Regulation, the amount of salt in TS should be less than $5 \%$ in tulum cheeses (Ministry of Agriculture and Forestry 2015). Salt in TS content of the Söğle cheese samples were found to be higher than the limit value prescribed by the Turkish Food Codex. This may be due to the fact that Sögle cheese is produced by a different method than other tulum cheeses.

Fatty acid (FA) compositions of lipid fraction from cheese samples are given in Table II. Free fatty acids (FFA), especially short- and mediumchain fatty acids, which are the result of lipolysis in cheese, directly contribute to the cheese flavor (Park 2001). Short and medium chain fatty acids in four Söğle cheese samples were listed as capric acid (C10:0), caprylic acid (C8:0), caproic acid (C6:0) and butyric acid (C4:0) according to their contents. These results are in agreement with the results of Sengul et al. (2014), who reported that capric acid was the main short chain FFA present in the tulum cheese samples produced with different coagulants. Palmitic acid (C16:0), oleic acid (C18:1 n-9), myristic acid (C14:0) and stearic acid (C18:0) were the long chain fatty acids with the highest ratios in Söğle cheese samples. Palmitic acid was found to be a major fatty acid in all Söğle cheese samples. Similar results were reported by Sert et al. (2014) where the contents of palmitic acid were the highest with 28.87 and $28.80 \%$ of total FAs contents in 90-day-ripened tulum cheeses produced by using raw and pasteurized goat's milk, respectively. The values of saturated short and medium-chain (C4:0 to C12:0) FAs content of milk fat in Söğle cheese samples ranged from $16.83 \%$ to $25.07 \%$ with an average of $21.99 \%$. Yilmaz et al. (2005) have reported the average values for the sum of short (C4:0-C8:0) and medium-chain (C10:0-C14:0) fatty acids for tulum cheeses with 
TABLE II

Fatty acid compositions (g/100g of total fatty acids) of Söğle cheese samples ripened for three months $(n=2)^{*}$.

Cheese Samples

Fatty acids (\%)

\begin{tabular}{|c|c|c|c|c|c|}
\hline & C1 & $\mathrm{C} 2$ & $\mathrm{C} 3$ & $\mathrm{C} 4$ & $\mathrm{C5}$ \\
\hline $\mathrm{C} 4: 0$ & $1.4 \pm 0.1$ & $1.0 \pm 0.0$ & $0.9 \pm 0.0$ & $0.6 \pm 0.0$ & $3.6 \pm 0.1$ \\
\hline C6:0 & $2.9 \pm 0.0$ & $2.9 \pm 0.0$ & $2.6 \pm 0.0$ & $1.5 \pm 0.4$ & $2.4 \pm 0.0$ \\
\hline C7:0 & $0.1 \pm 0.0$ & $0.1 \pm 0.0$ & nd & nd & nd \\
\hline C8:0 & $4.0 \pm 0.0$ & $3.6 \pm 0.0$ & $2.9 \pm 0.0$ & $2.7 \pm 0.0$ & $2.9 \pm 0.1$ \\
\hline C9:0 & nd & nd & $0.2 \pm 0.0$ & nd & $0.4 \pm 0.0$ \\
\hline C10:0 & $10.2 \pm 0.1$ & $10.3 \pm 0.1$ & $8.1 \pm 0.0$ & $7.5 \pm 0.0$ & $9.0 \pm 0.1$ \\
\hline C11:0 & $0.5 \pm 0.0$ & $0.8 \pm 0.0$ & $0.7 \pm 0.0$ & $0.1 \pm 0.0$ & nd \\
\hline C11:1 n-1 & $0.3 \pm 0.0$ & $0.1 \pm 0.0$ & $0.1 \pm 0.0$ & nd & $0.1 \pm 0.0$ \\
\hline C12:0 & $6.1 \pm 0.0$ & $6.1 \pm 0.0$ & $5.0 \pm 0.0$ & $4.4 \pm 0.1$ & $5.7 \pm 0.1$ \\
\hline $\mathrm{C} 14: 0$ & $12.7 \pm 0.0$ & $9.6 \pm 0.1$ & $12.9 \pm 0.0$ & $11.2 \pm 0.1$ & $13.0 \pm 0.2$ \\
\hline $\mathrm{C} 14: 1 \mathrm{n}-5$ & $0.3 \pm 0.0$ & $0.3 \pm 0.0$ & $0.5 \pm 0.0$ & $0.3 \pm 0.0$ & $0.6 \pm 0.0$ \\
\hline $\mathrm{C} 15: 0$ & $0.7 \pm 0.0$ & $0.1 \pm 0.0$ & $1.3 \pm 0.0$ & $1.2 \pm 0.0$ & $1.0 \pm 0.0$ \\
\hline $\mathrm{C} 15: 1 \mathrm{n}-5$ & $0.2 \pm 0.0$ & $0.1 \pm 0.0$ & $0.1 \pm 0.0$ & $0.2 \pm 0.0$ & $0.2 \pm 0.0$ \\
\hline $\mathrm{C} 16: 0$ & $24.8 \pm 0.3$ & $28.2 \pm 0.3$ & $29.2 \pm 0.1$ & $30.3 \pm 0.5$ & $32.1 \pm 0.6$ \\
\hline $\mathrm{C} 16: 1 \mathrm{n}-7$ & $1.0 \pm 0.0$ & $1.1 \pm 0.1$ & $1.3 \pm 0.0$ & $0.6 \pm 0.1$ & $1.6 \pm 0.0$ \\
\hline $\mathrm{C} 17: 0$ & $0.5 \pm 0.0$ & $0.4 \pm 0.0$ & $0.7 \pm 0.0$ & $0.4 \pm 0.0$ & $0.2 \pm 0.0$ \\
\hline C17:1 n-7 & $0.3 \pm 0.0$ & $0.8 \pm 0.1$ & $0.6 \pm 0.0$ & $0.8 \pm 0.1$ & $0.7 \pm 0.0$ \\
\hline C18:0 & $5.9 \pm 0.1$ & $7.8 \pm 0.1$ & $6.1 \pm 0.2$ & $11.2 \pm 0.2$ & $4.1 \pm 0.1$ \\
\hline C18:1 n-9 & $19.7 \pm 0.2$ & $19.2 \pm 0.0$ & $19.1 \pm 0.1$ & $19.0 \pm 0.1$ & $15.1 \pm 0.3$ \\
\hline C18:2 n-6 & $1.8 \pm 0.0$ & $3.2 \pm 0.1$ & $2.5 \pm 0.0$ & $3.3 \pm 0.1$ & $1.3 \pm 0.0$ \\
\hline C18:3 n-6 & $1.5 \pm 0.0$ & $0.9 \pm 0.0$ & $1.1 \pm 0.0$ & $1.1 \pm 0.1$ & $1.6 \pm 0.0$ \\
\hline C18:3 n-3 & $0.8 \pm 0.0$ & $0.6 \pm 0.0$ & $0.7 \pm 0.0$ & $0.6 \pm 0.2$ & $0.6 \pm 0.0$ \\
\hline C20:0 & $0.3 \pm 0.0$ & $0.1 \pm 0.0$ & $0.4 \pm 0.0$ & $0.2 \pm 0.0$ & $0.5 \pm 0.0$ \\
\hline Others & $3.9 \pm 0.0$ & $2.7 \pm 0.1$ & $2.8 \pm 0.0$ & $2.8 \pm 0.2$ & $3.4 \pm 0.0$ \\
\hline$\sum \mathrm{C} 4: 0$ to $\mathrm{C} 9: 0$ & $8.4 \pm 0.1$ & $7.6 \pm 0.1$ & $6.6 \pm 0.1$ & $4.9 \pm 0.5$ & $9.3 \pm 0.2$ \\
\hline$\sum \mathrm{C} 4: 0$ to $\mathrm{C} 12: 0^{* *}$ & $25.1 \pm 0.0$ & $24.1 \pm 0.0$ & $19.9 \pm 0.0$ & $16.8 \pm 0.1$ & $24.1 \pm 0.1$ \\
\hline$\sum \mathrm{C} 10: 0$ to $\mathrm{C} 15: 1$ & $31.0 \pm 0.3$ & $27.4 \pm 0.2$ & $28.8 \pm 0.1$ & $24.9 \pm 0.3$ & $29.6 \pm 0.5$ \\
\hline$\sum \mathrm{C} 14: 0$ to $\mathrm{C} 20: 0^{* *}$ & $44.5 \pm 0.1$ & $46.3 \pm 0.1$ & $50.6 \pm 0.1$ & $54.5 \pm 0.2$ & $50.9 \pm 0.2$ \\
\hline$\sum \mathrm{C} 16: 0$ to $\mathrm{C} 20: 0$ & $56.8 \pm 0.8$ & $62.3 \pm 0.7$ & $61.8 \pm 0.6$ & $67.4 \pm 1.3$ & $57.8 \pm 1.1$ \\
\hline SFAs & $69.9 \pm 0.8$ & $70.4 \pm 0.6$ & $70.5 \pm 0.6$ & $71.4 \pm 1.4$ & $75.0 \pm 1.4$ \\
\hline MUFAs & $22.0 \pm 0.3$ & $22.2 \pm 0.2$ & $22.3 \pm 0.2$ & $20.9 \pm 0.3$ & $18.2 \pm 0.4$ \\
\hline PUFAs & $4.2 \pm 0.1$ & $4.7 \pm 0.1$ & $4.3 \pm 0.1$ & $4.9 \pm 0.4$ & $3.5 \pm 0.1$ \\
\hline
\end{tabular}

nd: non determined, SFAs: Saturated fatty acids, MUFAs: Monounsaturated fatty acids, PUFAs: Polyunsaturated fatty acids, ${ }^{* *}$ : Sum of saturated fatty acids. 
microbial lipase at different ratios as $24-25 \mathrm{~g} / 100 \mathrm{~g}$ cheese and 21-22g/100g cheese, respectively. Similarly, reported values for the sum of saturated short and medium-chain (C4 to C12) FAs of 15 Uruguayan goat cheese samples ranged from $13.50 \%$ to $27.70 \%$ (20.70\% average) (Vieitez et al. 2016). In terms of long chain fatty acids, the average content of the sum of saturated fatty acids (C14:0-C20:0) for five Söğle cheese samples was about $50 \%$ of total FAs contents. Karagozlu et al. (2009) have reported similar ratios for the sum of saturated C14:0-C20:0 fatty acids in Cimi tulum cheeses. As indicated in Table II, SFAs and MUFAs in the Söğle cheeses were determined to be respectively $69.9-75.0 \%$ and $18.2-22.3 \%$. Our results are also agreement with the results of Kinik et al. (2005).

A total of 53 volatile compounds were detected by SPME-GC-MS analysis in all cheese samples, and were classified into the following chemical groups: esters (5.74\%), acids (10.66\%), ketones $(43.63 \%)$, aldehydes $(0.38 \%)$, alcohols $(8.83 \%)$, terpenes $(29.61 \%)$ and miscellaneous $(1.16 \%)$ (Table III). Ketones and terpenes were the predominant volatile compounds. Carboxylic acid contents and esters were relatively low in the studied cheeses due to their low fat contents.

Ketones, which have typical odors and low perception thresholds (Bontinis et al. 2012), are the products of lipid degradation formed by $\beta$-oxidation and decarboxylation of fatty acids (Poveda et al. 2008). Seven ketones were identified in Söğle cheese samples with 2-butanone being the most abundant compound in all cheese samples (Table III). 2-Butanone was previously detected as the major ketone compound in different goat milk cheeses including Gokceada (Hayaloglu et al. 2013b), Xinotyri (Bontinis et al. 2012), Ibores (Delgado et al. 2011) and Teleme (Massouras et al. 2006). 2-Butanone is responsible for the buttery odor, and it derives from 2,3-butanedione (diacetyl) during lactose or citrate metabolism by microorganisms (McSweeney and Sousa 2000, Hayaloglu et al. 2013a). 2-Heptanone, 2-nonanone and 3-hydroxy-2-butanone (acetoin) were also detected in most of the studied cheeses (Table III). These ketones have been detected in different goat cheese types (Le Quéré et al. 1998, Poveda et al. 2008, Boltar et al. 2016).

Terpenes are secondary plant metabolites that are ingested by herbivores and subsequently found in associated animal-origin foods including milk. Terpene content of forage varies greatly according to the plant species (Cornu et al. 2005). Therefore, terpenes are important for determining the geographical origin of a cheese (Cornu et al. 2005, Bontinis et al. 2012). Twelve terpenes were identified in the cheeses with a mean percentage of $29.61 \pm 8.89$. Limonene was the most abundant (from 17.11 to $31.11 \%$ ) terpene compound in all cheeses. High limonene content was found in soft raw goat cheese by Sablé et al. (1997). Limonene has been reported to be associated with citrus-like flavor in some cheeses (Nogueira et al. 2005). Limonene were also found at low levels in 60day- ripened Gokceada goat milk cheeses and 90-day-ripened Ibores goat milk cheeses studied by Hayaloglu et al (2013b) and Delgado et al. (2011), respectively. $\beta$-myrcene, $p$-cymene, $\beta$-pinene and $\gamma$ -terpinene were detected in all the cheese samples (Table III). Similarly, $\beta$-myrcene, $\alpha$ - and $\beta$-pinene and caryophyllene were determined in traditional Greek goat cheese Xinotyri (Bontinis et al. 2012). The differences in terpene profiles of Söğle cheese samples in this research may be explained by the differences in consumed herbs by the small ruminants, differences in cheese production steps and microbial flora differences among the cheeses (Cornu et al. 2005).

It was well known that carboxylic acids were formed by three main biochemical pathways (proteolysis, lipolysis and glycolysis) during cheese ripening (McSweeney and Sousa 2000). Carboxylic acids were the third most abundant 
TABLE III

Relative abundance (\%) of volatile compounds isolated from Söğle cheese samples $(n=2)$.

\begin{tabular}{|c|c|c|c|c|c|c|c|}
\hline \multirow{2}{*}{ Compounds } & \multicolumn{5}{|c|}{ Cheese Samples } & \multirow{2}{*}{ Mean } & \multirow{2}{*}{ SD } \\
\hline & $\mathrm{C1}$ & $\mathrm{C2}$ & $\mathbf{C 3}$ & $\mathrm{C4}$ & $\mathrm{C5}$ & & \\
\hline \multicolumn{8}{|l|}{ Esters } \\
\hline Ethyl butanoate & 0.17 & - & 2.13 & 0.11 & 0.46 & 0.57 & 0.89 \\
\hline Ethyl 9-decenoate & - & - & - & - & 0.10 & 0.02 & 0.04 \\
\hline Ethyl decanoate & 0.91 & 1.04 & 2.40 & 2.33 & 2.53 & 1.84 & 0.80 \\
\hline 3-Methylbutyl acetate & 0.19 & - & - & - & 0.08 & 0.05 & 0.08 \\
\hline Ethyl hexanoate & 1.59 & 0.29 & 1.87 & 1.11 & 1.01 & 1.17 & 0.61 \\
\hline 2-Methylpropyl hexanoate & 0.42 & - & 0.21 & 0.22 & 0.08 & 0.19 & 0.16 \\
\hline 2-Phenethyl acetate & - & - & - & - & 0.29 & 0.06 & 0.13 \\
\hline Ethyl myristate & - & - & - & 0.22 & 0.22 & 0.09 & 0.12 \\
\hline Isobutyl decanoate & - & - & - & - & 0.18 & 0.04 & 0.08 \\
\hline Ethyl octanoate & 1.09 & 0.69 & 1.73 & 1.59 & 1.70 & 1.36 & 0.45 \\
\hline Hexanoic acid, 3-methylbutyl- ester & - & - & - & - & 0.11 & 0.02 & 0.05 \\
\hline Ethyl benzoate & - & - & - & 0.15 & 0.07 & 0.04 & 0.07 \\
\hline Ethyl laurate & - & - & 0.39 & 0.44 & 0.57 & 0.28 & 0.26 \\
\hline Total & 4.37 & 2.02 & 8.73 & 6.17 & 7.40 & 5.74 & 2.63 \\
\hline \multicolumn{8}{|l|}{ Acids } \\
\hline Acetic acid & 11.20 & 6.82 & 7.31 & 4.93 & 7.10 & 7.472 & 2.29 \\
\hline Butanoic acid & 0.51 & - & - & 0.32 & 0.43 & 0.25 & 0.24 \\
\hline Hexanoic acid & 0.86 & 0.44 & 2.16 & 0.26 & 0.26 & 0.80 & 0.80 \\
\hline Octanoic acid & 1.21 & 0.67 & 1.95 & 0.19 & 0.30 & 0.86 & 0.73 \\
\hline Decanoic acid & 0.96 & 0.26 & 4.91 & 0.11 & 0.13 & 1.27 & 2.06 \\
\hline Total & 14.74 & 8.19 & 16.33 & 5.81 & 8.22 & 10.66 & 4.59 \\
\hline \multicolumn{8}{|l|}{ Ketones } \\
\hline 2-Butanone & 51.97 & 27.28 & 27.06 & 38.51 & 33.05 & 35.57 & 10.31 \\
\hline 3-Hydroxy-2-butanone & 0.74 & 0.62 & - & 1.02 & 1.38 & 0.75 & 0.51 \\
\hline 2-Pentanone & - & 1.47 & 0.57 & - & - & 0.41 & 0.64 \\
\hline 2-Heptanone & 0.52 & 10.89 & 0.56 & - & - & 2.39 & 4.76 \\
\hline 2-Nonanone & 0.46 & 19.93 & 0.36 & - & 0.28 & 4.21 & 8.79 \\
\hline 8-Nonen-2-one & - & 0.88 & - & - & - & 0.18 & 0.39 \\
\hline Undecan-2-one & - & 0.62 & - & - & - & 0.12 & 0.28 \\
\hline Total & 53.69 & 61.69 & 28.55 & 39.53 & 34.71 & 43.63 & 13.70 \\
\hline \multicolumn{8}{|l|}{ Aldehydes } \\
\hline Benzaldehyde & - & 0.17 & 0.27 & 1.04 & - & 0.30 & 0.43 \\
\hline 3-Methyl propanal & - & 0.40 & - & - & - & 0.08 & 0.18 \\
\hline Total & - & 0.57 & 0.27 & 1.04 & - & 0.38 & 0.44 \\
\hline \multicolumn{8}{|l|}{ Alcohols } \\
\hline Ethanol & 7.40 & 4.88 & 10.66 & 8.15 & 9.75 & 8.17 & 2.24 \\
\hline 3-Methyl-1-butanol & 0.65 & 0.32 & 0.33 & 0.31 & 0.42 & 0.41 & 0.14 \\
\hline 2-Heptanol & 0.20 & 0.26 & - & - & - & 0.09 & 0.13 \\
\hline
\end{tabular}


TABLE III (continuation)

\begin{tabular}{|c|c|c|c|c|c|c|c|}
\hline \multirow{2}{*}{ Compounds } & \multicolumn{5}{|c|}{ Cheese Samples } & \multirow{2}{*}{ Mean } & \multirow{2}{*}{ SD } \\
\hline & $\mathrm{C1}$ & $\mathrm{C2}$ & C3 & $\mathrm{C4}$ & C5 & & \\
\hline 2-Nonanol & - & 0.27 & - & - & 0.07 & 0.07 & 0.12 \\
\hline 2-Phenethyl alcohol & - & 0.09 & - & - & 0.38 & 0.09 & 0.16 \\
\hline Total & 8.25 & 5.82 & 10.99 & 8.46 & 10.62 & 8.83 & 2.09 \\
\hline \multicolumn{8}{|l|}{ Terpenes } \\
\hline Limonene & 17.11 & 18.10 & 22.77 & 32.44 & 31.11 & 24.31 & 7.16 \\
\hline$\beta$-Myrcene & 1.17 & 1.36 & 1.63 & 1.30 & 1.42 & 1.38 & 0.17 \\
\hline p-Cymene & 0.34 & 0.65 & 4.83 & 1.05 & 1.13 & 1.60 & 1.83 \\
\hline$\alpha$-Pinene & 0.00 & 0.40 & 1.04 & 1.27 & 0.58 & 0.66 & 0.51 \\
\hline$\beta$-Pinene & 0.23 & 0.60 & 0.64 & 1.03 & 1.33 & 0.77 & 0.42 \\
\hline$\alpha$-Thujene & - & - & - & 0.14 & 0.19 & 0.07 & 0.09 \\
\hline Carene & - & - & - & - & 0.23 & 0.05 & 0.10 \\
\hline Sabinene & - & - & - & 0.09 & 0.17 & 0.05 & 0.08 \\
\hline$\delta$-3-Carene & - & - & - & - & 0.49 & 0.10 & 0.22 \\
\hline$\gamma$-Terpinene & 0.10 & 0.23 & 0.29 & 0.17 & 0.33 & 0.22 & 0.09 \\
\hline$\alpha$-Terpinolene & - & - & 1.58 & - & 0.25 & 0.37 & 0.69 \\
\hline Caryophyllene & - & - & - & 0.26 & - & 0.05 & 0.12 \\
\hline Total & 18.95 & 21.34 & 32.78 & 37.75 & 37.23 & 29.61 & 8.89 \\
\hline \multicolumn{8}{|l|}{ Miscellaneous } \\
\hline 3,7-Dimethyl-1,6-octadiene & - & - & 1.27 & - & - & 0.25 & 0.57 \\
\hline 3,7-Dimethyl-2-octene & - & - & 0.31 & - & - & 0.06 & 0.14 \\
\hline p-Dichlorobenzene & - & 0.19 & - & 0.11 & 0.10 & 0.08 & 0.08 \\
\hline 1-Methyl-4-isopropenylbenzene & - & - & 0.57 & - & - & 0.11 & 0.25 \\
\hline 3,7-Dimethylundecane & - & - & - & - & 0.06 & 0.01 & 0.03 \\
\hline Tetradecane & - & 0.18 & - & - & - & 0.04 & 0.08 \\
\hline Styrene & - & - & - & 0.38 & 1.68 & 0.41 & 0.73 \\
\hline 3-Methyl phenol & - & - & 0.21 & 0.19 & - & 0.08 & 0.11 \\
\hline Dimethyl disulfide & - & - & - & 0.55 & - & 0.11 & 0.25 \\
\hline Total & - & 0.37 & 2.36 & 1.23 & 1.84 & 1.16 & 0.98 \\
\hline
\end{tabular}

volatile compounds isolated from the Söğle cheeses at the end of 90-day ripening period. Five carboxylic acids were detected and acetic acid was the most abundant carboxylic acid (ranging from 4.93 to $11.20 \%$ ) in all the cheese samples. Acetic acid was also detected as the most abundant carboxylic acid in different goat milk cheeses including starter-free Gokceada goat cheese (Hayaloglu et al. 2013b) and Xinotyri cheese (Bontinis et al. 2012). Butanoic (rancid), hexanoic (sour/dirty/sweet), octanoic (sweaty/fatty/rancid/ goat) and decanoic (waxy/rancid/cheese/dry) acids, which are formed by lipolysis and contribute to cheese flavor (Poveda et al. 2008, Ozmen Togay et al. 2017), were also detected in the cheese samples. These fatty acids have been identified in different goat cheeses previously (Carunchia Whetstine et al. 2003, Chiofalo et al. 2004, Ozmen Togay et al. 2017).

Esters are significant cheese flavor contributors due to their high volatility at ambient temperatures (Bontinis et al. 2012). They are formed by the 
esterification of short- to medium-chain fatty acids and primary and secondary alcohols (Engels et al. 1997). Thirteen ester compounds were detected in Söğle cheese samples, and constituted 2.02-7.40\% of the total volatile fraction. The most abundant esters were ethyl esters; ethyl decanoate, ethyl octanoate and ethyl hexanoate were present in all studied cheese samples. Ethyl butanoate (0.11$2.13 \%$ ) was also detected in the cheese samples except cheese sample C2 (Table III). Ethyl esters were also the predominant esters found in different goat cheeses such as Maltese (Chiofalo et al. 2004), semi-hard Spanish goat cheese (Poveda et al. 2008) and Gokceada artisanal goat cheese (Hayaloglu et al. 2013b). Ethyl laurate was detected in three Söğle cheese samples. This compound is the ester of ethyl alcohol and lauric acid and has a light, fruity odor (Winter 2009). Ethyl laurate was also identified in Sicilian goat cheese by Mondello et al. (2005). Esters detected in cheese are described as having sweet, fruity (especially ethyl esters) with floral notes at low concentrations and yeasty notes at high concentrations (Engels et al. 1997, Curioni and Bosset 2002, Delgado et al. 2011). Esters can contribute to cheese flavor by minimizing the sharpness imparted by fatty acids and the bitterness from amines (Curioni and Bosset 2002).

Aldehydes originate from amino acids either by transamination or Strecker degradation. They are transitory compounds and are not concentrate in cheese because they are rapidly transformed to alcohols or the corresponding acids (Hayaloglu et al. 2013a, b, Delgado et al. 2011). Only two aldehydes (benzaldehyde and/or 3-methyl propanal) were detected in three Söğle cheese samples. Benzaldehyde, which is responsible for bitter almond note, has been detected in some goat cheeses (Hayaloglu et al. 2013a, b, Kondyli et al. 2016). The branched aldehyde 3-methylpropanal was listed amongst the odor compounds of Grana Padano cheese (Moio and Addeo 1998) and Blue cheese (Heath 1981). According to Moio and Addeo
(1998), very low levels of aldehydes in cheeses indicated a regular ripening and their higher levels are responsible for serious off-flavor.

A total of five alcohols were detected in ripened Söğle cheeses. Ethanol had the highest level among the total volatile fraction of cheese samples with $4.88-10.66 \%$. Ethanol was also detected as most abundant alcohol compound in numerous goat milk cheeses (Sablé et al. 1997, Mondello et al. 2005, Massouras et al. 2006, Bontinis et al. 2012). Ethanol, which plays a significant role in formation of esters, is mostly produced by the fermentation of lactose and by the catabolism of alanine (Hayaloglu et al. 2013b). 3-methyl-1-butanol, a branched-chain primary alcohol, was identified in low abundance in all the cheese samples in our study. 3-methyl1-butanol, which have lower detection thresholds (Delgado et al. 2011), is formed by the reduction of the aldehyde produced from leucine (Curioni and Bosset 2002) and gave a fruity/floral note (Sablé et al. 1997). It was identified in different goat milk cheeses (Delgado et al. 2011, Hayaloglu et al. 2013a, Boltar et al. 2016). Small relative abundances of 2-heptanol, 2-nonanol and 2-phenethyl alcohol in some Söğle cheeses were determined. These alcohols were also detected in ewe's milk cheeses ripened in tulums or plastic bags (Hayaloglu et al. 2007) and some other goat cheeses (Mondello et al. 2005, Boltar et al. 2016). Phenylethanol, is among the most odorous aromatic alcohols, is responsible for rose flower notes (Curioni and Bosset 2002).

Nine miscellaneous compounds were detected at very low percentages in four Söğle cheese samples. Styrene, which is responsible for a strong plastic odor, was detected only in two cheese samples. Six hydrocarbons, a phenolic compound (3-methyl phenol) and a sulfur compound (dimethyl disulfide) were also identified. Hydrocarbons are secondary products of lipid autoxidation and are precursors for aromatic compounds formation (Hayaloglu et al. 2007). Sulfur compounds, which are the result of degradation of methionine and 
TABLE IV

Microbiological properties of Söğle cheese samples after ripening period of three months $(n=2)^{*}$.

\begin{tabular}{cccccc}
\hline \multirow{2}{*}{$\log \mathbf{~ c f u} / \mathbf{g}$} & $\mathbf{C 1}$ & $\mathbf{C 2}$ & $\mathbf{C h}$ & $\mathbf{C 4}$ & $\mathbf{C 5}$ \\
\cline { 2 - 6 } & $8.2 \pm 0.2$ & $7.1 \pm 0.0$ & $7.8 \pm 0.0$ & $7.6 \pm 0.1$ & $8.5 \pm 0.1$ \\
\hline Lactobacillus spp. & $8.4 \pm 0.0$ & $7.8 \pm 0.0$ & $7.9 \pm 0.1$ & $7.8 \pm 0.0$ & $8.7 \pm 0.0$ \\
Lactococcus spp. & $8.5 \pm 0.1$ & $7.6 \pm 0.1$ & $7.9 \pm 0.1$ & $7.9 \pm 0.0$ & $8.3 \pm 0.0$ \\
${ }^{* * *}$ TAMB & $1.0 \pm 0.0$ & $4.8 \pm 0.1$ & $2.6 \pm 0.0$ & $2.0 \pm 0.0$ & $4.0 \pm 0.1$ \\
Yeast and mould &
\end{tabular}

"The presented values are the means \pm standard deviation $(\mathrm{n}=2) .{ }^{* *}$ TAMB: Total Aerobic Mesophilic Bacteria.

cysteine, give garlic, onion, or very ripe cheese odors (Bontinis et al. 2012).

The results of some microbial properties of Söğle cheese samples are shown in Table IV. At the end of 90-day-ripening period, mean counts of Lactobacillus spp. and Lactococcus spp. in the cheese samples were found to be between 7.1 and $8.5 \log \mathrm{cfu} / \mathrm{g}$ and 7.8 and $8.7 \log \mathrm{cfu} / \mathrm{g}$, respectively. Gurses and Erdogan (2006) reported that many of LAB isolated tulum cheese samples belong to the genus Lactobacillus, the number of Lactobacillus in the samples increased during the ripening period, and the number of other genera did not change in a significant amount. Lactococcus counts of Söğle cheese samples were higher than those found in some other tulum cheese samples, which were below 7 log cfu/g (Karagozlu et al. 2009, Oner et al. 2004). However, Cakmakci et al. (2008) stated that the Lactococcus species rapidly disappeared three months after the ripening period for tulum cheese samples. The total aerobic mesophilic bacteria counts ranged from 7.6 to $8.5 \log \mathrm{cfu} / \mathrm{g}$, while the counts of yeast and mould varied from 1.0 to $4.8 \log \mathrm{cfu} / \mathrm{g}$ in Söğle cheese samples. These results are in agreement with the results of Karagozlu et al. (2009), who reported that average amounts were determined as $8.5 \mathrm{log} \mathrm{cfu} / \mathrm{g}$ for total mesophilic bacteria and $1.6 \log \mathrm{cfu} / \mathrm{g}$ for yeast in Cimi tulum cheeses. Oksuztepe et al. (2005) found that the total aerobic mesophilic bacteria and yeast and mold counts in Savak tulum cheeses produced using raw sheep's milk were $2.2 \times 10^{7}$ and $2.7 \times 10^{4}$ $\mathrm{cfu} / \mathrm{mL}$, respectively. The counts of total aerobic mesophilic bacteria in tulum cheeses packed in goat skin, plastic barrels and ceramic pots were 7.8, 6.8 and $5.9 \log \mathrm{cfu} / \mathrm{g}$, respectively (Ceylan et al. 2007). These differences in microbiological properties in tulum cheeses, including Söğle cheese, could be related to the production methods, storage time and conditions, chemical composition and acidity of the cheeses, and the interaction between the microorganisms, as well as raw milk microflora used in cheese production.

\section{CONCLUSIONS}

As the first scientific study on traditional Söğle cheese, physicochemical and microbiological properties, fatty acid composition and volatile profile of five different Söğle cheeses ripened for three months were presented in this paper. In general, chemical composition parameters such as TS, salt, salt in TS, fat, fat in TS, protein and protein in TS in the Söğle cheese samples were different from those of other tulum cheeses due to differences in the production process and/ or chemical and microbiological properties of milk used for cheese production. Capric acid and palmitic acid were the main short and long chain FFAs, respectively in all the Söğle cheese samples, while the fatty acid compositions of all the cheese samples were quite different among them. Ketones and terpenes were the predominant volatile chemical components in the isolated fifty three compounds. Like other tulum cheeses such as 
Savak, Divle and Cimi tulum cheeses, Lactobacillus and Lactococcus spp. constituted the dominant microflora. Söğle cheese with low fat content may be appealing to tulum cheese consumers who prefer foods low in fat content. Although Söğle cheese is locally produced and sold at relatively higher prices, there is a need for standardized production process for Söğle cheese to expand its production and consumption. Therefore, future studies should focus on establishing a standard production process for Söğle cheese.

\section{ACKNOWLEDGMENTS}

The authors are grateful to Dilek Boğatimur, Ali Kaya, Elif Kaya, Faruk Kaya, Zehra Kaya and Hilal Tuncer for their precious help during collection of cheese samples, and to Prof. Dr. Yildirım Atayeter for his help during the preparation of the location maps. Dr. Hale Seçilmiş Canbay and Dr. Sermin Karagöz are acknowledged for their technical assistance during cheese analysis.

\section{REFERENCES}

ADANACIOGLU H AND ALBAYRAM Z. 2012. A conjoint analysis of consumer preferences for traditional cheeses in Turkey: A case study on tulum cheese. Korean J Food Sci An 32(4): 58-46.

BAYAR N AND OZRENK E. 2011. The effect of quality properties on Tulum cheese using different package materials. Afr J Biotechnol 10(8): 1393-1399.

BOLTAR I, ČANŽEK MAJHENIČ A, JUG T, MUJIĆ I, JOKIĆ S AND BAVCON KRALJ M. 2016. The impact of some parameters on volatile compounds in hard type cheeses. Croat J Food Sci and Technol 8(2): 74-82.

BONTINIS THG, MALLATOU H, PAPPAEC, MASSOURAS TH AND ALICHANIDIS E. 2012. Study of proteolysis, lipolysis and volatile profile of a traditional Greek goat cheese (Xinotyri) during ripening. Small Rumin Res 105: 193-201.

CAKMAKCI S, DAGDEMIR E, HAYALOGLU AA, GURSES M AND GUNDOGDU E. 2008. Influence of ripening container on the lactic acid bacteria population in Tulum cheese. World J Microbiol Biotechnol 24: 293-299.

CARUNCHIAWHETSTINE ME, KARAGUL-YUCEER Y, AVSAR YK AND DRAKE MA. 2003. Identification and quantification of character aroma components in fresh Chevre-style goat cheese. J Food Sci 68: 2441-2447.

CELIK OF AND TARAKCI Z. 2017. The effects of starter cultures on chemical, biochemical and sensory properties of low-fat Tulum cheeses during ripening. Int J Dairy Technol 70: 1-9.

CEYLAN ZG, CAGLAR AAND CAKMAKCI S. 2007. Some physicochemical, microbiological, and sensory properties of tulum cheese produced from ewe's milk via a modified method. Int J Dairy Technol 60(3): 191-197.

CHIOFALO B, ZUMBO A, COSTA R, LIOTTA L, MONDELLO L, DUGO P AND CHIOFALO V. 2004. Characterization of Maltese goat milk cheese flavor using SPME-GC/MS. S Afr J Anim Sci 34(Suppl. 1): 176-180.

CORNU A, KONDJOYAN N, MARTIN B, VERDIER-METZ I, PRADEL P, BERDAGUÉ JL AND COULON JB. 2005. Terpene profiles in Cantal and Saint-Nectaire-type cheese made from raw or pasteurised milk. J Sci Food Agric 85: 2040-2046.

CURIONI PMG AND BOSSET JO. 2002. Key odorants in various cheese types as determined by gas chromatographyolfactometry. Int Dairy J 12: 959-984.

DELGADO FJ, GONZALEZ-CRESPO J, CAVA R AND RAMIREZ R. 2011. Formation of the aroma of a raw goat milk cheese during maturation analysed by SPME-GCMS. Food Chem 129: 1156-1163.

DINKCI N, AKALIN AS, GONÇ S AND UNAL G. 2007 Isocratic reverse-phase HPLC for determination of organic acids in Kargi tulum cheese. Chromatographia 66(Suppl 1): 45-49.

DINKCI N, UNAL G, AKALIN AS, VAROL S AND GONC S. 2012. Karg1 tulum peynirinin kimyasal ve mikrobiyolojik özellikleri. Ege Univ Zir Fak Derg 49: 287-292.

ENGELS WJM, DEKKER R, DE JONG C, NEETER R AND VISSER S. 1997. A comparative study of volatile compounds in the water-soluble fraction of various types of ripened cheese. Int Dairy J 7: 255-263.

GUINEE TP. 2004. Salting and the role of salt in cheese. Int J Dairy Technol 57: 99-109.

GURSES M AND ERDOGAN A. 2006. Identification of lactic acid bacteria isolated from Tulum cheese during ripening period. Int J Food Prop 9: 551-557.

HAYALOGLU AA, CAKMAKCI S, BRECHANY EY, DEEGAN KC AND MCSWEENEY PL. 2007. Microbiology, biochemistry, and volatile composition of Tulum cheese ripened in goat's skin or plastic bags. J Dairy Sci 90: 1102-1121.

HAYALOGLU AA, TOLU C, YASAR K AND SAHINGIL D. 2013a. Volatiles and sensory evaluation of goat milk cheese Gokceada as affected by goat breeds (Gokceada and Turkish Saanen) and starter culture systems during ripening. J Dairy Sci 96: 2765-2780. 
HAYALOGLU AA, YASAR K, TOLU C AND SAHINGIL D. 2013b. Characterizing volatile compounds and proteolysis in Gokceada artisanal goat cheese. Small Rum Res 113: 187-194.

HEATH HB. 1981. Source book of flavors. New York: AVI Book, 864 p.

KARAGOZLU C, KILIC S AND AKBULUT N. 2009. Some characteristics of Cimi Tulum cheese from producing goat milk. Bulg J Agric Sci 15(4): 292-297.

KAROUI R, BOSSET JO, MAZEROLLES G, KULMYRZAEV A AND DUFOUR E. 2005. Monitoring the geographic origin of both experimental French Jura hard cheeses and Swiss Gruyère and L'Etivaz PDO cheeses using mid-infrared and fluorescence spectroscopies: a preliminary investigation. Int Dairy J 15: 275-286.

KINIK O, GURSOY O AND SECKIN AK. 2005. Cholesterol content and fatty acid composition of most consumed Turkish hard and soft cheeses. Czech J Food Sci 23: 166172.

KONDYLI E, PAPPA EC AND SVARNAS C. 2016. Ripening changes of the chemical composition, proteolysis, volatile fraction and organoleptic characteristics of a white-brined goat milk cheese. Small Rum Res 145: 1-6.

LE QUÉRÉ JL, PIERRE A, RIAUBLANC A AND DEMAIZIÈRES D. 1998. Characterization of aroma compounds in the volatile fraction of soft goat cheese during ripening. Lait 78: 279-290.

MASSOURAS T, PAPPA EC AND MALLATOU H. 2006. Headspace analysis of volatile flavour compounds of teleme cheese made from sheep and goat milk. Int J Dairy Technol 59: 250-256.

MCSWEENEY PLH AND SOUSA MJ. 2000. Biochemical pathways for the production of flavour compounds in cheese during ripening: a review. Lait 80: 293-324.

MINISTRY OF AGRICULTURE AND FORESTRY. 2015. Turkish food codex cheese notification. Ankara, Turkey: No. 2015/6.

MOIO L AND ADDEO F. 1998. Grana Padano cheese aroma. J Dairy Res 65: 317-333.

MONDELLO L, COSTAR, TRANCHIDA PQ, CHIOFALO B, ZUMBO A, DUGO PAND DUGO G. 2005. Determination of flavor components in Sicilian goat cheese by automated HS-SPME-GC. Flavour Fragr J 20: 659-665.

NOGUEIRA MCL, LUBACHEVSKY G AND RANKIN SA. 2005. A study of the volatile composition of Minas cheese. LWT-Food Sci Technol 38: 555-563.

OKSUZTEPE G, PATIR B AND CALICIOGLU M. 2005. Identification and distribution of lactic acid bacteria during the ripening of Şavak tulum cheese. Turk J Vet Anim Sci 29: 873-879.

ONER Z, SAGDIC O AND SIMSEK B. 2004. Lactic acid bacteria profiles and tyramine and tryptamine contents of
Turkish tulum cheeses. Eur Food Res Technol 219: 455459.

OZMEN TOGAY S, GUNESER O AND KARAGUL YUCEER Y. 2017. Evaluation of physicochemical, microbiological, sensory properties and aroma profiles of goat cheeses provided from Canakkale. Int J Dairy Technol 70: 514-525.

PARK YW. 2001. Proteolysis and lipolysis of goat milk cheese. J Dairy Sci 84: 84-92.

POVEDA JM, SANCHEZ-PALOMO E, PEREZ-COELLO MS AND CABEZAS L. 2008. Volatile composition, olfactometry profile and sensory evaluation of semi-hard Spanish goat cheeses. Dairy Sci Technol 88: 355-367.

RENNER E. 1993. Milchpraktikum Skriptum zu den Übüngen, Giesen: Justus Liebig Universitat, p. 76.

SABLÉ S, LETELLIER F AND COTTENCEAU G. 1997. An analysis of the volatile flavor compounds in a soft raw goat milk cheese. Biotechnol Lett 19: 143-146.

SENGUL M, ERKAYA T, DERVISOGLU M, AYDEMIR O AND GUL O. 2014. Compositional, biochemical and textural changes during ripening of Tulum cheese made with different coagulants. Int J Dairy Technol 67: 373-383.

SERT D AND AKIN N. 2008. Production methods of some important traditional tulum cheeses in Turkey. In: $10^{\text {th }}$ Turkish Food Congress. Proceedings, Erzurum, p. 20.

SERT D, AKIN N AND AKTUMSEK A. 2014. Lipolysis in Tulum cheese produced from raw and pasteurized goats' milk during ripening. Small Rum Res 121: 351-360.

SHAHBAZI Y, NIKOUSEFAT Z AND KARAMI N. 2017. Occurrence, seasonal variation and risk assessment of exposure to aflatoxin M1 in Iranian traditional cheeses. Food Control 79: 356-362.

TARAKCI Z AND DURMUS Y. 2016. Effects of packaging materials on some ripening characteristics of Tulum cheese. Mljekarstvo 66: 293-303.

TURKISH STANDARDS INSTITUTE. 1995. Turkish standard for white brined cheese. TS 591, Ankara.

VIEITEZ I, IRIGARAY B, CALLEJAS N, GONZALEZ V, GIMEREZ S, ARECHAVALETA A, GROMPONE M AND GAMBARO A. 2016. Composition of fatty acids and triglycerides in goat cheeses and study of the triglyceride composition of goat milk and cow milk blends. J Food Compost Anal 48: 95-101.

WINTER R. 2009. A consumer's dictionary of food additives. $7^{\text {th }}$ ed., New York: Three Rivers Press, 608 p.

YILMAZ G, AYAR A AND AKIN N. 2005. The effect of microbial lipase on the lipolysis during the ripening of Tulum cheese. J Food Eng 69: 269-274.

YILMAZER M AND SECILMIS H. 2006. Investigation of the derivatization conditions of some free fat acids in methanolic $\mathrm{HCl}$ medium. In: III National Analytical Chemistry Congress, Proceedings, Çanakkale, p. 422-424. 